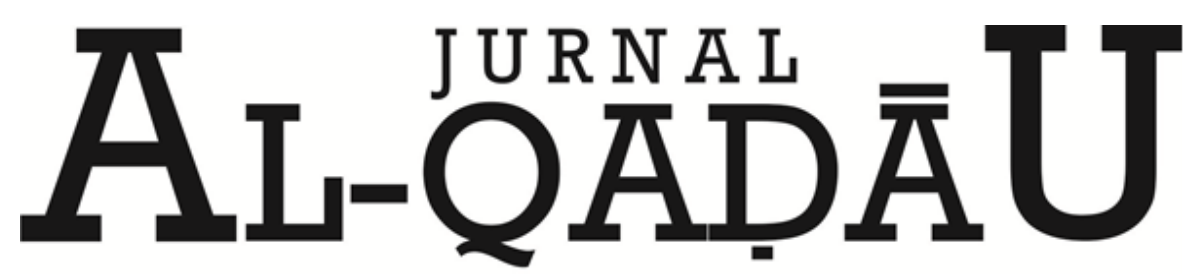

PERADILAN dan HUKUM KELUARGA ISLAM

\title{
Mahkamah Konstitusi di Beberapa Negara Perspektif Perbandingan Hukum
}

Constitutional Court in Several Countries in a Comparative Legal Perspective

Andi Safriani

Dosen Fakultas Syariah dan Hukum UIN Alauddin Makassar

Email: aydinriany13@gmail.com

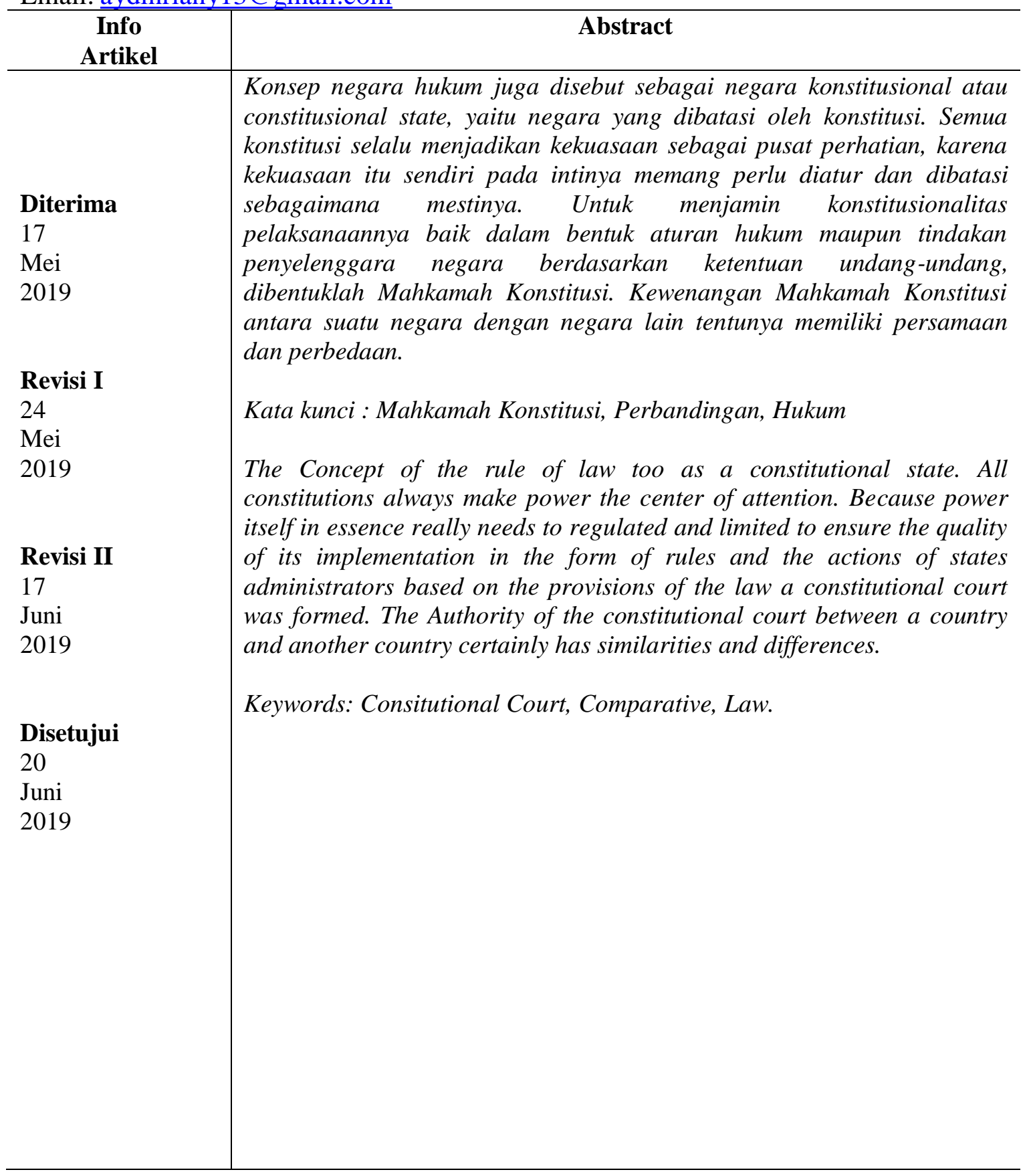




\section{A. PENDAHULUAN}

Salah satu ciri negara hukum adalah adanya pembatasan kekuasaan dalam penyelenggaraan kekuasaan negara. Pembatasan itu dilakukan dengan hukum yang kemudian menjadi ide dasar paham konstitusionalisme modern. Oleh karena itu konsep negara hukum juga disebut sebagai negara konstitusional atau konstitusional state, yaitu negara yang dibatasi oleh konstitusi. Semua konstitusi selalu menjadikan kekuasaan sebagai pusat perhatian, karena kekuasaan itu sendiri pada intinya memang perlu diatur dan dibatasi sebagaimana mestinya.

Pembatasan konsitusi pada umumnya dianggap merupakan corak umum materi konstitusi agar konstitusi benar-benar menjadi hukum tertinggi,maka ketentuanketentuan dasar konstitusional harus dilaksanakan melalui peraturan perundangundangan dibawah konstitusi. Untuk menjamin konstitusionalitas pelaksanaannya baik dalam bentuk aturan hukum maupun tindakan penyelenggara negara berdasarkan ketentuan undang-undang, dibentuklah Mahkamah Konstitusi yang memiliki wewenang salah satunya adalah memutus pengujian undang-undang terhadap Undang-Undang Dasar.

Keberadaan Mahkamah Konstitusi merupakan fenomena baru dalam dunia ketatanegaraan. Sebagian besar negara demokrasi yang sudah mapan tidak mengenal lembaga Mahkamah Konstitusi yang berdiri sendiri. Sampai sekarang baru ada 78 negara yang membentuk mahkamah konstitusi ini secara tersendiri. Fungsinya biasanya dicakup dalam fungsi-fungsi supreme court yang ada disetiap negara. Seperti di Amerika Serikat.

Kewenangan Mahkamah Konstitusi antara suatu negara dengan negara lain tentunya memiliki persamaan dan perbedaan. Hal ini sangat dipengaruhi oleh sejarah suatu bangsa.

\section{B. METODE PENELITIAN}

Adapun jenis penelitian yg digunakan adalah library research yaitu metode penelitian dengan mengkaji berbagai literatur dan sumber lainnya yang memiliki relevansi dengan topik yang dibahas. Pendeketan penelitian yang digunakan penulis dalam tulisan ini adalah pendekatan perundang-undangan (statuta aproach) dan pendekatan perbandingan (comparative aproach)dengan mengkaji perbandingan mahkamah konsitusi dibeberapa negara. Adapun teknik pengolahan dan analisis data yang digunakan penulis adalah dengan mengumpulkan data kemudian dianalisa secara kualitatif selanjutnya disajikan secara deskriptif dengan memberikan penjelasan gambaran dari permasalahan yang berkaitan erat dengan penulisan ini.

\section{PEMBAHASAN}

\section{Mahkamah Konstitusi Indonesia}

Kedudukan Mahkamah Konstitusi di Indonesia adalah sebagai lembaga negara yang baru yang sederajat atau sama tinggi kedudukannya dengan Mahkamah Agung. Menurut ketentuan Undang-Undang Dasar 1945 pasca amandemen ke 4 tahun 2002, dalam struktur kelembagaan di Indonesia terdapat 9 buah organ negara yang secara langsung menerima kewenangan dari Undang-undang Dasar 1945, salah satu diantaranya adalah Mahkamah Konstitusi.

Mahkamah Konstitusi merupakan pelaksana kekuasaan kehakiman (yudiciary) yang merdeka dan terpisah dari cabang-cabang kekuasaan lainnya yakni pemerintah 
(eksekutif) dan lembaga perwakilan (legislative), baik Mahkamah Agung maupun Mahkamah Konstitusi keduanya berkedudukan di Jakarta sebagai Ibu Kota Negara.

\section{Kewenangan Mahkamah Konstitusi di Indonesia}

Undang-Undang Dasar 1945 menentukan bahwa Mahkamah Konstitusi mempunyai 4 kewenangan konstitusional (Constitusionally untrusted powers) dan satu kewajiban konstitusional. Ke 4 kewenangan itu adalah :

1) Menguji undang-undang (UU) terhadap Undang-Undang Dasar.

2) Memutuskan sengketa kewenangan antar lembaga negara yang kewenangannya diberikan oleh Undang-Undang Dasar.

3) Memutuskan sengketa hasil pemilihan umum.

4) Memutuskan pembubaran partai politik.

Adapun kewajiban konstitusional dari Mahkamah Konsitusi adalah memutus pendapat DPR bahwa Presiden dan atau Wakil Presiden telah berslah melakukan pelanggaran hukum ataupun tidak lagi memenuhi persyaratan sebagai Presiden atau Wakil Presiden seperti yang di maksud dalam UUD 1945.

\section{Pengangkatan Hakim Mahkamah Konstitusi di Indonesia.}

Pasal 24C ayat 4 Undang-Undang Dasar 1945 dan pasal 4 ayat 1 Undangundang No.24 tahun 2003 Tentang Mahkamah Konstitusi menegaskan bahwa Mahkamah Konstitusi mempunyai 9 orang anggota hakim konstitusi yang ditetapkan oleh keputusan Presiden, 9 orang hakim konstitusi ini diisi oleh calon yang dipilih oleh tiga lembaga , yakni: DPR, Presiden dan Mahkamah Agung.

Pembagian porsi kewenangan untuk mengajukan calon hakim konstitusi dari tiga lembaga tersebut dimaksudkan untuk menjamin agar dalam menjalankan tugas konstitusionalnya, para hakim konstitusi ini akan bersikap imparsial dan independent. Apalagi salah satu kewenangan dari Mahkamah Konstitusi adalah memutus sengketa kewenangan antar lembaga negara, sehingga mengharuskan para hakim konstitusi un tuk secara moral dan hukum bersikap netral dan tidak berpihak kepada salah satu lembaga negara yang bersengketa.

\section{Mahkamah Konstitusi Perancis}

Dewan Konstitusi Perancis didirikan pada tahun 1958, semula ide pembentukan organ ini memang didesain untuk melucuti kekuasaan Parlemen. Oleh karena itu, organ yang disebut Conseil Constitutionnel sering pula dikatakan sebagai bentuk paling mutakhir dari system pengujian konstitusional. Akibatnya model pengujian ala Perancis banyak diadopsi oleh model constitutional review yang terdapat dinegara-negara Eropa.

Dalam perkembangannya Dewan Konstitusi dipandang tidak hanya sekadar melaksanakan kewenangan tradisionalnya, yakni mengawasi aktivitas parlemen. Saat itu, Dewan Konstitusi Perancis ikut terlibat dalam menentukan arah kebijakan negara. Ini disebabkan karena setiap rancangan undang-undang yang akan diundangkan harus mendapat persetujuan dari organ tersebut.

Komposisi anggota Dewan Konstitusi Perancis termaktub dalam Konsitusi Republik kelima Perancis 1958 dalam Pasal 56 diatur, bahwa anggota Dewan Konsitusi ditentukan oleh tiga institusi kenegaraan, yakni:

1. 3 orang diangkat oleh Presiden

2. 3 orang diangkat oleh Ketua Majelis Nasional 
3. 3 orang diangkat oleh Ketua Senat

Praktik yang berkembang dewasa ini, criteria umum untuk mengisi komposisi dewan konstitusi dilakukan melalui afiliasi politik. Akibatnya, keanggotaan dewan konsitusi didomonasi oleh politis professional. Berbeda halnya dengan Jerman, Spanyol dan Italia yang menggabungkan dua model dalam menentukan komposisi Mahkamah Konstitusi, yaitu melalui cara pengangkatan disatu sisi dan pemilihan disisi lainnya.

Dewan Konstitusi memiliki tanggungjawab penuh dalam menguji tingkat keselarasan produk hukum dengan konstitusi. Hal ini meliputi undang-undang organic (secara umum) dan peraturan tata tertib permanen National Assembly dan Senate. Disamping itu, pengujian juga dapat diarahkan kepada perjanjian internasional (Article) yang dibuat oleh pemerintah. Putusan Dewan Konstitusi itu sendiri bersifat final mengikat terhadap seluruh kekuasaan publk, kewenangan administrative maupun badan peradilan lainnya.

\section{Mahkamah Konstitusi Afrika Selatan}

Afrika Selatan adalah negara dimana salah satu kelompok masyarakatnya pernah mengalami penindasan. Saat itu kehidupan orang-orang Afrika Selatan diisolasi di perumahan kota satelit tersendiri

Telaah empiris menunjukkan bahwa proses kompromi dan rekonsiliasi guna mengakhiri rezim aphartheid diawali dengan menyusun draf rancangan Konstitusi sementara, konstitusi tersebut disahkan pada tanggal 22 Desember 1993 dan mulai berlaku secara efektif pada tanggal 27 April 1994. Dalam bab yang mengatur tentang hak-hak fundamental secara terang benderang dikatakan bahwa Mahkamah Konstitusi Afrika Selatan dapat membatalkan undang-undang ataupun tindakan pemerintah jika dinilai telah membatasi kebebasan dasar umat manusia.

Komposisi Mahkamah Konstitusi Afrika Selatan terdiri atas Presiden,Deputi Presiden,dan Sembilan hakim anggota lainnya. Dengan demikian, jumlah keseluruhan anggota Mahkamah Konstitusi Afrika Selatan adalah 11 orang.

Perkara yang diajukan kepada Mahkamah Konstitusi pertama-tama akan didengar oleh panel yang paling sedikit terdiri atas delapan orang hakim. Bagi Afrika Selatan Mahkamah Konstitusi adalah Pengadilan tertinggi terhadap seluruh perkara konstitusional. Sebab itu, mahkamah hanya dapat memutus perkara konstitusional dan putusannya bersifat final dan mengikat.

Presiden dan Deputi Presiden Mahkamah Konstitusi Afrika Selatan diangkat oleh Presiden Afrika Selatan sebagai Kepala Pemerintahan. Namun, Presiden Afrika Selatan harus terlebih dahulu melakukan konsultasi dengan Judicial Service Commision (Komisi Yudisial) dan pemimpin-pemimpin partai politik yang terdapat dalam majelis nasional. Sembilan hakim Mahkamah Konstitusi juga diangkat oleh Presiden setelah berkonsultasi dengan Presiden Mahkamah Konstitusi dan pemimpin-pemimpin partai politik dalam Majelis Nasional. Di samping itu, Presiden Afrika Selatan juga mengangkat hakim pengganti Mahkamah Konstitusi jika berlangsung kekosongan jabatan hakim. Pengangkatan ini harus memperoleh rekomendasi dari anggota kabinet yang bertanggungjawab atas penyelenggaraan administrasi kehakiman.

Hakim Mahkamah Konstitusi Afrika Selatan diangkat untuk masa jabatan satu kali 12 tahun dan hakim akan memasuki masa purna bakti jika mencapai umur 70 tahun. Model rekrutmen dan durasi jabatan di Mahkamah Konstitusi Afrika Selatan dapat 
dikatakan diilhami oleh sistem yang berlaku di Jerman. Seperti diketahui bahwa Mahkamah Konstitusi Jerman terdiri atas 16 hakim yang diangkat oleh supermayoritas Parlemen. Masa jabatan hakim Mahkamah Konstitusi di Jerman juga 12 tahun dan tidak dapat diangkat kembali.

Berdasarkan Pasal 167 ayat 3 Konstitusi Afrika Selatan mengatur bahwa Mahkamah Konstitusi adalah Pengadilan tertinggi untuk seluruh perkara konstitusional. Jika ditelaah secara komparatif, strukur hierarki demikian menyerupai posisi Mahkamah Agung Amerika Serikat, ketika organ itu berperan sebagai Peradilan banding tertinggi atas seluruh perkara yang timbul dari pengadilan-pengadilan federal. Namun, diantara keduanya memiliki identitas yang membedakan secara nyata. Mahkamah Agung Amerika Sertikat dapat menyelesaikan semua jenis perkara yang dalam system kekuasaan kehakiman di Indonesia lazim disebut tingkat kasasi. Sebaliknya, Mahkamah Konstitusi Afrika Selatan hanya daapat bertindak sebagai Pengadilan Banding khusus terhadap perkara-perkara yang berhubungan dengan pelanggaran konstitusi.

Berdarkan ketentuan dalam konsitusi Afrika Selatan, maka Mahkamah Konstitusi Afrika Selatan memiliki lima kewenangan yakni:

1. Decide dispute between organs of state in national of provincial sphere concering the constitutional status, power of function of any those organs of state,

2. Decide application envisage in section 80 ' or 122 ,

3. Decide on the constitutionality of any amendement tp the constitution,

4. An Decide that parlement or the president has failed to fulfill a constitutional obligation, or

5. Certify a provincial constitution in terms on section 144.

Mahkamah Konstitusi akan memutus final konstitusionalitas undang-undang yang diproduksi oleh parlemen,peraturan perundang-undangan daerah ataupun tindakan dari Afrika Selatan. Disamping itu Mahkamah memberi jawaban defenitif atas permintaan pembatalan suatu ketentuan hukum yang dimohonkan oleh Mahkamah Agung,Pengadilan tinggi ataupun Pengadilan lainnya.

\section{Mahkamah Konstitusi Hungaria}

Hungaria pada masa-masa sebelumnya merupakan negara yang mengakui mengakui eksistensi kekuasaan absolute dibawah sistem kerajaan konservatif. Ketika itu Sainst Stephen adalah pewaris Mahkota Suci (Holy Grown) yang bertindak sebagai satu-satunya symbol bagi kerajaan kristiani saat itu. Perspektif sejarah menjelaskan bahwa periode ini disebut dark passion yang telah membawa Hungaria terperosok kedalam system pemerintahan berideologi fasis.

Berbagai perkembangan penting terjadi setelah berakhirnya rezim fasis sejalan dengan pendekatan demokratisasi. Dalam konteks historis system politik Hungaria pernah berada dibawah kendali rezim komunis. Kendati demikian, setelah pemerintah pasca komunis mengambil kendali kekuasaan, mahkota kembali memperlihatkan wujud serta menempati posisi sebagai symbol negara. Kondisi tersebut melahirkan kompetisi atas konsepsi dalam menggagas pembentukan konstitusi baru Hungaria. Perkembangan yang khas dan dramatis ini, akhirnya menciptakan persaingan diantara pengusung perubahan konstitusi dengan pemuja doktrin mahkota suci di sisi lain. 
Mahkamah Konstitusi Hungaria menjadi suatu preseden yang mengikuti model Mahkamah Konstitusi yang berkembang di wilayah Eropa Barat, terutama dalam menentukan arti dari konsitusi. Gagasan ini sangat dipengaruhi tradisi.

Dengan demikian, tatanan konstitusional Hungaria sangat dipengaruhi oleh interaksi-interaksi yang melahirkan kesepakatan antara elemen-elemen politik tentang urgensi mewujudkan prinsip konstgitusionalisme dan Republik demokratik, dimana keduanya telah mendasarkan diri pada konsep negara hukum. Dalam Pengertian ini, persoalan tersebut tentu tidak dapat dilepaskan dari keberlakuan konstitusi sebagai hukum dasar yang mengikat serta didasarkan atas kekuasaan tertinggi atau prinsip kedaulatan dalam suatu negara.

Pembentukan Mahkamah Konstitusi Hungaria dipenghujung Januari 1989, Parlemen Hungaria mencapai kesepakatan, Parlemen Hungaria mencapai kesepakatan untuk membentuk pengadilan yang terlepas sama sekali dari cabang Peradilan umum. Oleh karena itu, Mahkamah adalah institusi terpisah organ konstitusional, dan memiliki kekuasaan secara eksklusif dalam menjalankan uji konstitusional produk legislatif. Sejak awal pola Mahkamah Konstitusi Hungaria dibicarakan melalui kerangka negosiasi trilateral. Hal ini dilakukan karena Hungaria sepakat menjalankan proses transformasi demokratik atas system politiknya secara damai.

Berdasarkan hasil perubahan konstitusi Hungaria, Parlemen pada oktober 1989 mengesahkan undang-undang nomor XXXII tentang Mahkamah Konstitusi. Mahkamah Konstitusi Hungaria mulai menjalankan seluruh kewenaangannya pada 1 Januari 1990.

Dengan melaksanakan kewenangannya, Mahkamah Konstitusi meningkatkan kepastian hukum (legal certainty) terhadap makna keadilan substantive. Dalam proses transisional menuju demokrasi Mahkamah Konstitusi Hungaria ini merupakan bentuk perkembangan generasi ketiga Mahkamah Konstitusi Eropa, setelah negara Austria, Spanyol dan Portugal.

Mahkamah Konstitusi merupakan organ utama dan pertama dalam melindungi konstitusi. Mahkamah bertugas menguji konstitusionalitas undang-undang, dan melindungi tatanan konstitusional serta hak-hak fundamental yang dijamin secara tegas dan jelas dalam konstitusi.

Mahkamah Konstitusi Hungaria terdiri atas 11 orang anggota. Ketua dan wakil ketua Mahkamah Konstitusi dipilih dari dan oleh hakim Mahkamah Konstitusi untuk masa jabatan 3 tahun. Putusan Mahkamah Konstitusi adalah mengikat sifatnya dan tidak dapat dibanding. Putusan yang berkenaan dengan konstitusionalitas undang-undang ditentukan melalui siding pleno yang harus dihadiri oleh seluruh hakim. Sedangkan dalam menentukan konstitusionalitas peraturan pemerintah dapat ditentukan melalui panel hakim yang terdiri atas tiga orang hakim, kemudian hasilnya ditentukan melalui suara mayoritas serta dilakukan dalam siding tertutup.

Melalui Undang-undang XXXII tahun 1989, Mahkamah Konstitusi Hungaria memiliki 8 kewenangan, yaitu:

1. Pengujian secara ex ante atas rancangan undang-undang, tata tertib parlemen sebelum diberlakukan dan perjanjian internasional sebelum ditetapkan.

2. Pengujian secara ex post atas undang-undang dan juga peraturan perundangundangan lain yang ditetapkan oleh pemerintah negara.

3. Menguji perselisihan antara perjanjian internasional dengan undang-undang dan juga peraturan perundang-undangan lain yang ditetapkan oleh pemerintahan negara. 
4. Memutus permohonan konstitusional berkenaan dengan pelanggaran hakhak konstitusional yang dijamin oleh konstitusi.

5. Menyisihkan suatu hal yang tidak konstitusional akibat kelalaian.

6. Menghentikan sengketa kewenangan diantara lembaga-lembaga negara dengan pemerintahan daerah atau lembaga pemerintah lainnya ataupun sengketa kewenangan pemerintahan daerah.

7. Interpretasi konstitusi

8. Memeriksa seluruh perkara terkait dengan pelanggaran konstitusi.

Mekanisme peradilan konsitusi (konstitutional adjudication) itu sendiri baru kita adopsi kedalam sistem konstitusi negara kita dengan dibentuknya Mahkamah Konstitusi. Beragam Mahkamah konstitusi diberbagai negara mempunyai persamaan dan perbedaan satu sama lain. Perbedaannya antara lain disebabkan karena masingmasing negara memiliki karakteristik sendiri-sendiri.

\section{PENUTUP}

\section{Kesimpulan}

1. Konstitusi menjadi sesuatu yang urgen dalam kehidupan bernegara, terutama bagi Negara hukum (rechstaat) yang demokratis. Dalam Negara hukum yang demokratis, Demokrasi diatur dan dibatasi olehaturan hukum, sedangkan hukum itu sendiri ditentukan melalui cara-cara yang demokratis berdasarkan konstitusi, dengan demikian aturan dasar penyelenggaraan Negara harus disandarkan kembali secara konsisten pada konstitusi.

2. Untuk menjamin konstitusionalitas pelaksanaannya baik dalam bentuk aturan hukum maupun tindakan penyelenggara negara berdasarkan ketentuan undang-undang, dibentuklah Mahkamah Konstitusi yang memiliki wewenang salah satunya adalah memutus pengujian undang-undang terhadap Undang-Undang Dasar.

3. Keberadaan Mahkamah Konstitusi merupakan fenomena baru dalam dunia ketatanegaraan. Sebagian besar negara demokrasi yang sudah mapan tidak mengenal lembaga Mahkamah Konstitusi yang berdiri sendiri. Sampai sekarang baru ada 78 negara yang membentuk mahkamah konstitusi ini secara tersendiri. Kewenangan Mahkamah Konstitusi antara suatu negara dengan negara lain tentunya memiliki persamaan dan perbedaan. 


\section{DAFTAR PUSTAKA}

Asshidiqie, Jimly. Peradilan Konstitusi di 10 Negara. Jakarta: Sinar Grafika. 2011. 2017. , Pengantar Ilmu Hukum Tata Negara. Jakarta: Raja Grafindo Persada,

Bogdan, Michael. Pengantar Perbandingan Sistem Hukum. Bandung: Nusa Media. 2010.

Cruz, Peter de. Perbandingan Sistem Hukum. Bandung: Nusa Media. 2010.

Huda, Ni'matul. Hukum Tata Negara Indonesia. Jakarta: Raja Grafindo Persada, 2015.

Menski, Werner. Perbandingan Hukum dalam Konteks Global. Bandung: Nusa Media, 2012.

Sidharta, Bernard Arif. Refleksi tentang Struktur Ilmu Hukum, Bandung, Mandar Maju. 2000.

Suherman, Ade Maman. Pengantar Perbandingan Sistem Hukum. Jakarta: Raja Grafindo Persada. 2012,

www.google.com "Kedudukan Mahkamah Konstitusi dalam Strukur Ketatanegaraan di Indonesia”, diakses 4 januari 2019.

www.googlee.com “Perbandingan Mahkamah Konstitusi Beberapa Negara”, diakses 4 Januari 2019. 